Proceedings of XIX International Scientific Conference "New Technologies and Achievements in Metallurgy, Material Engineering, Production Engineering and Physics", Częstochowa, Poland, June 7-8, 2018

\title{
Depth Corrosion Characteristics of Borided Layer Produced on AISI 321 Stainless Steel
}

\author{
K. JAGIELSKA-WIADEREK* \\ Czestochowa University of Technology, Faculty of Production Engineering and Materials Technology, \\ Department of Chemistry, al. Armii Krajowej 19, 42-201 Czestochowa, Poland
}

\begin{abstract}
This paper presents the results of effects of boronizing process of AISI 321 austenitic stainless steel on its electrochemical corrosion resistance. The steel samples were boronized at a temperature of $900^{\circ} \mathrm{C}$ for $6 \mathrm{~h}$. In this process, a mixture powder $\left(\mathrm{B}_{4} \mathrm{C}, \mathrm{SiC}\right.$, borax $)$, alumina $\left(\mathrm{Al}_{2} \mathrm{O}_{3}\right)$ and potassium fluoroborate $\left(\mathrm{KBF}_{4}\right)$ was used. The evaluation of the corrosion resistance of boronized stainless steel was carried out by using the so-called progressive thinning method, consisting in determination of polarisation characteristics on increasingly-deeper situated regions of the top layer. This method made it possible to determine changes in particular corrosion parameters read out from potentiodynamic polarisation curves, thus enabling the depth profiles of these parameters. Potentiodynamic polarization tests were carried out in an $0.5 \mathrm{M}$ sulphate solution acidified to $\mathrm{pH}=2.0$. It is shown that unlike unmodified steel, the boron-rich outer layer does not passivate but undergoes fast dissolution both in active- and transpassive regions in the corrosion solution.
\end{abstract}

DOI: 10.12693/APhysPolA.135.252

PACS/topics: corrosion, stainless steel, boronizing

\section{Introduction}

Austenitic stainless steels containing $12 \div 25$ wt $\% \mathrm{Cr}$ and $8 \div 25$ wt $\% \mathrm{Ni}$ are the most widely used $\mathrm{Fe}-\mathrm{Cr}-\mathrm{Ni}$ ternary alloys in the stainless steel family. These steels are widely used for heat exchangers, steam generators, acid tanks, agitators, pump units, etc. [1, 2]. The excellent corrosion resistance of $\mathrm{Cr}-\mathrm{Ni}$ stainless steels depends on the presence of chromium; resistance to corrosion increases with increase of chromium content. Passive layers spontaneously formed on the surface of these steels contain mainly $\mathrm{Cr}_{2} \mathrm{O}_{3}, \mathrm{Fe}_{2} \mathrm{O}_{3}$ and $\mathrm{NiO}$ oxides and also $\mathrm{NiM}_{2} \mathrm{O}_{4}$ spinels $(\mathrm{M} \equiv \mathrm{Cr}$ or $\mathrm{Fe}$ ) and have strongly ionic insulating properties $[3,4]$. Despite its superior corrosion properties, stainless steels applications have been limited because it has a low hardness and poor wear performance $[5,6]$. A distinct increase in the functional properties and operation durability of tools and mechanical parts can be achieved by employing the thermochemical treatment of the steel surface.

The boriding process is an effective technique to improve some surface properties, such as: corrosion, hardness, fatigue strength, wear resistance, etc. [7-9]. The improvement of the mechanical properties of the steel surface is a result of the formation of boride inclusions in the outer layers. When applied on steels, it forms iron boride layers which can be made up of two phases $\left(\mathrm{FeB} / \mathrm{Fe}_{2} \mathrm{~B}\right)$ or just one phase $(\mathrm{FeB})$, depending on the boron potential on the outer steel surface, the process temperature, and the exposure time. For industrial applications,

\footnotetext{
*e-mail: jagielska-wiaderek.karina@wip.pcz.pl
}

the formation of an $\mathrm{Fe}_{2} \mathrm{~B}$ monophase layer on the surface is more desirable than an $\mathrm{FeB}$ polyphase layer; whereas, the former occurs beneath the latter, because FeB has a very brittle structure with a hardness level of around $2300 \mathrm{HV}$, compared to that of $\mathrm{Fe}_{2} \mathrm{~B}$, which varies in the range of 1500-1700 HV [9]. As a result of boronizing stainless steels, the outer layers of iron borides are often enriched with chromium and nickel borides of the $\mathrm{CrB}$, $\mathrm{Cr}_{2} \mathrm{~B}, \mathrm{NiB}$, and $\mathrm{Ni}_{3} \mathrm{~B}$ types [10-12].

The present paper aims to characterize the microstructure and mechanical properties of a boron-rich layer obtained on austenitic stainless steel AISI 321, as well as to evaluate its corrosion behavior on the cross-section of its outer layers to determine the depth profiles of corrosion parameters.

\section{Experimental details}

The austenitic stainless steel of AISI 321 (type $\mathrm{X} 6 \mathrm{CrNiTi18-10)}$ has been boronized with the use of gascontact method within $6 \mathrm{~h}$ at a temperature of $900^{\circ} \mathrm{C}$. As a source of boron the Ekabor II composition, Bortec $\mathrm{GmBH}$ (main ingredients: silicon/boron carbides; powder size $<850 \mu \mathrm{m})$ mixed together with $\mathrm{KBF}_{4}$ activator and alumina filler has been applied. After the boronizing process, the steel surface was examined by optical microscopy (Neophot 32) and JEOL JSM-5400 scanning electron microscope at an accelerating voltage of $20 \mathrm{kV}$. Microhardness measurements of the polished samples from the cross-section were carried out using Vickers indenter with an applied load of $0.4903 \mathrm{~N}$ (HV 0.05).

Electrodes used for the polarization testing of the boronized AISI 321 steel had the form of rotating discs with an operating surface area of $0.2 \mathrm{~cm}^{2}$. Prior to each potentiodynamic measurement, parallel electrode layers 
of a thickness of $4 \div 10 \mu \mathrm{m}$ were taken off by polishing, while proceeding from the surface into the depth of the steel. The thickness of the layers ground off was determined from the mass loss of the examined disc electrode in relation to its initial mass, established with an accuracy of $\pm 0.02 \mathrm{mg}$. The methodology described above [13$15]$ is called the progressive thinning method. The corrosion properties of the layers were investigated using a CHI1130A electrochemical analyzer. The potentiodynamic polarization curves were measured in a conventional three-electrode glass cell with a $1.0 \mathrm{M} \mathrm{AgCl} / \mathrm{Ag}$ reference electrode $\left(E_{\mathrm{AgCl} / \mathrm{Ag}}^{\mathrm{eq}}=+0.22 \mathrm{~V}\right)$, platinum wire as an auxiliary electrode and boronized steel acting as a working electrode. An Ar-saturated 0.5 $\mathrm{M} \mathrm{Na}_{2} \mathrm{SO}_{4}$ solution acidified to $\mathrm{pH}=2.0\left(25 \pm 0.2^{\circ} \mathrm{C}\right)$ served as a test solution. The test electrodes were polarized in the anodic direction from $E_{\text {start }}=-0.5 \mathrm{~V}$ to $E_{\text {end }}=+1.9 \mathrm{~V}$ at a rate of $5 \mathrm{mV} \mathrm{s}^{-1}$, with disc rotational speed being equal to $12 \mathrm{rps}^{-1}$. Before the tests, the specimens were immersed in the corrosion solution for $0.5 \mathrm{~h}$ to reach a steady state (Open Circuit Potential (OCP)).

\section{Results and discussion}

Figure 1 shows the etched cross-sections of boride layers formed on the surfaces of AISI 321 steel after boronizing at $900^{\circ} \mathrm{C}$. As is well known, the thickness and phase composition of a boride layer strictly depend on the parameters of the boronizing treatment applied [16, 17]. In the case of acid resistant chromium-nickel steels, apart from the typical hard iron boride phases ( $\mathrm{FeB}$ and $\mathrm{Fe}_{2} \mathrm{~B}$ ), the presence of $\mathrm{CrB}$ and $\mathrm{Ni}_{3} \mathrm{~B}$ precipitates has also been approved $[9,10]$. In addition, some precipitates, such as carbides and, probably, borides are clearly observed along austenitic grain boundaries in an AISI 321 steel substrate (Fig. 1). As can be seen in Figs. 1 and 2, the boronized surface has four regions, namely: (1 and 2) separate layers containing borides, (3) a boron-rich diffusion zone, and (4) a substrate part unaffected by boron.

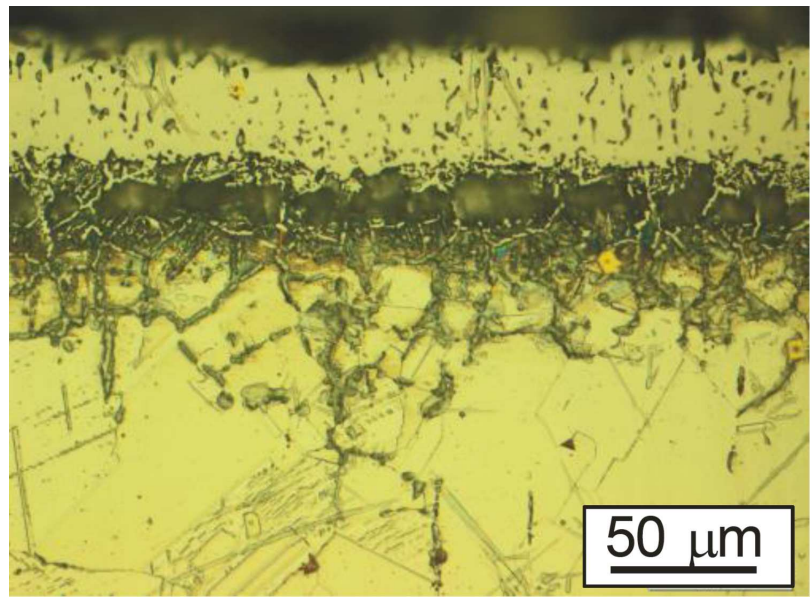

Fig. 1. Light micrographs showing the microstructure of a surface layer formed on AISI 321 steel after boronizing at $900^{\circ} \mathrm{C}$.

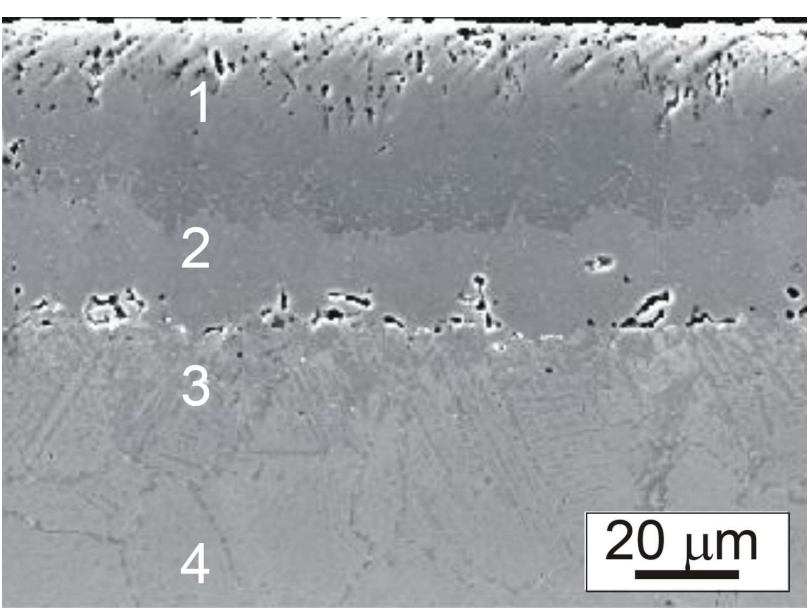

Fig. 2. A SEM image of AISI 321 steel as boronized at $900^{\circ} \mathrm{C}$ for $6 \mathrm{~h}$, showing distinct regions: separate layers containing borides ( 1 and 2 ), a diffusion zone (3), and a substrate (4).

A diphase layer is easily seen from the SEM micrograph in Fig. 2, where the FeB layer on the top surface (region 1$)$ is followed by an inner layer $\left(\mathrm{Fe}_{2} \mathrm{~B}\right.$ - region 2$)$ formed on the surface of the boronized specimen. Similar microstructures have been were obtained in boronized stainless steels by other authors [18-20].

Microhardness measurements were carried out from the surface to the interior along a straight line to observe variation in the hardness of the boride layer, the diffusion zone and the substrate, respectively. The depth profile of microhardness for the boronized steel specimens is presented in Fig. 3. An increased microhardness (compared to steel core) is observed for depths of up to $70 \mu \mathrm{m}$. The highest hardness values (over 2000 of HV 0.05 units) are measured in the first zone (see Fig. 2). The presence of hard FeB and, especially, CrB borides is an explanation for such a situation [18]. The second zone includes $\mathrm{Fe}_{2} \mathrm{~B}$ and $\mathrm{Cr}_{2} \mathrm{~B}$ borides. Therefore, lower hardness values

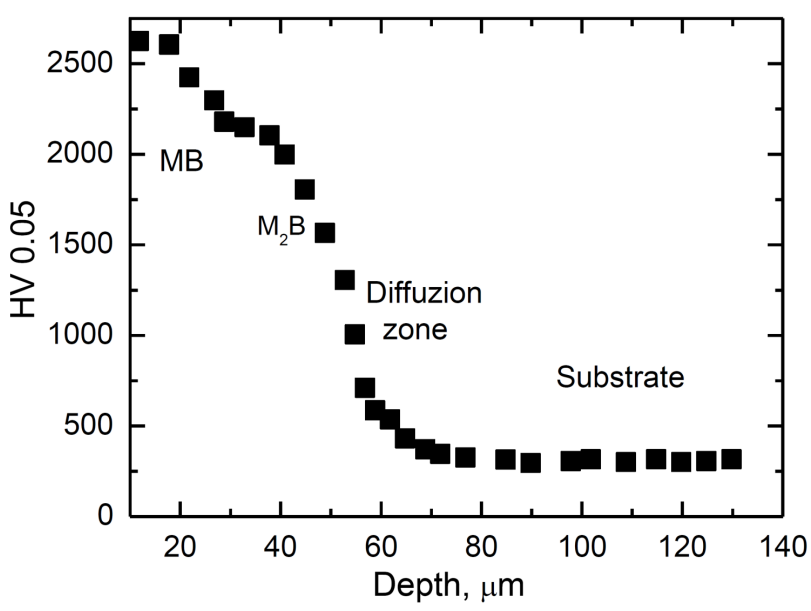

Fig. 3. Changes in microhardness on the cross-section of the surface layer of AISI 321 as steel boronized at $900{ }^{\circ} \mathrm{C}$ for $6 \mathrm{~h}$. 
(in the range of 1700 to $2000 \mathrm{HV}$ 0.05) are obtained. At depths of $>70 \mu \mathrm{m}$, i.e. within the diffusion zone where boride particulates exist, the microhardness rapidly decreases to attain a value of $c a .300 \mathrm{HV} 0.05$ (typical for the specimen interior, not affected by boron).

In Fig. 4a,b, potentiodynamic polarization curves registered at chosen distances from the initial surface of boronized AISI 321 steel are presented. As can be seen from Fig. 4, surface boron treatment does not affect the shapes of the potentiodynamic curves in the cathodic range and within the cathode-anodic transition. On the other hand, distinct differences in the shape of the polarization curves are observed in the anodic range. For steel in the initial state with $E>-0.2 \mathrm{~V}$, a clear drop in anodic current is observed (to $c a .0 .1 \mathrm{~mA} \mathrm{~cm}^{-2}$ ), which can be explained by the effective passivation of the steel. Borided steel AISI 321 behaves differently: above $-0.2 \mathrm{~V}$, it does not undergo passivation, but instead dissolves at high rates (active dissolution, the rate of $100 \mathrm{~mA} \mathrm{~cm}^{-2}$ ) up to potential $E=+0.5 \mathrm{~V}$. Above this potential value,
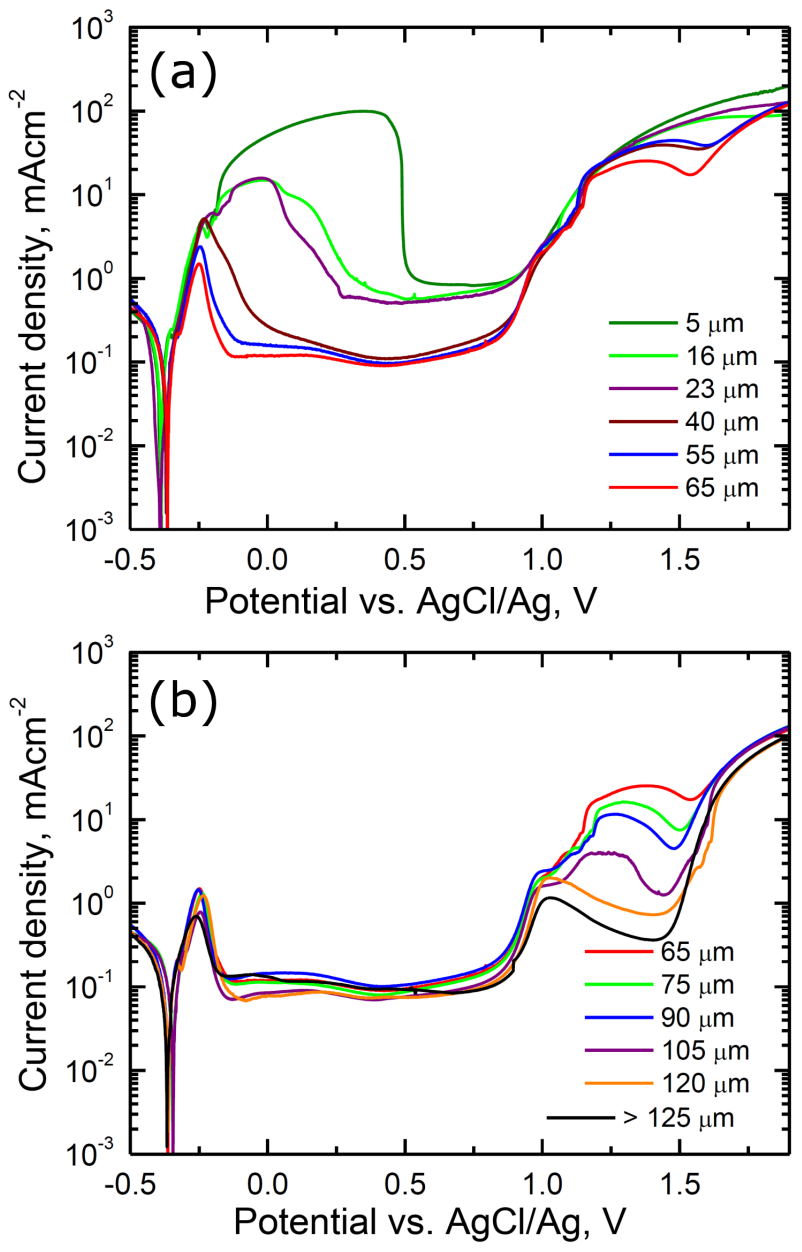

Fig. 4. Potentiodynamic polarization curves for the boronized AISI 321 steel and ground away to a specific depth $(\mu \mathrm{m})$, measured in $0.5 \mathrm{M}$ sulphate solutions $\mathrm{pH}=2.0$. Experimental conditions: $25^{\circ} \mathrm{C}$, stirring rate $12 \mathrm{rps}^{-1}$, potential scan rate $5 \mathrm{mV} \mathrm{s}^{-1}$ ). a short section of a not very effective passive state is observed for it $\left(E=+0.5 \div+0.9 \mathrm{~V}, i_{a} \approx 1 \mathrm{~mA} \mathrm{~cm}^{-2}\right)$, after which it dissolves transpassively $(E>+0.94 \mathrm{~V})$. While the initial steel above $E=+0.9 \mathrm{~V}$ exhibits some tendency to secondary passivation, the borided surface dissolves in the transpassive range at a considerable rate.

As shown in Fig. 4, boriding of the surface of steel AISI 321 impairs the anodic behaviour of the surface layer of this material, as evidenced by the increased values of anode currents. The changes of characteristic parameters read out from the polarization curves for consecutive top layers enable one to draw the depth profiles of these values. Figure 5 shows the depth profiles of the critical passivation current $\left(i_{c p}\right)$ and the minimum current within the passive range $\left(i_{\min . p}\right)$. Considerably increased values of the critical passivation current $i_{c p}$ are observed for the examined steel up to a depth of approximately $55-60 \mu \mathrm{m}$.

The depth, up to which the increased values of currents that characterize the readiness of transition into a passive state $\left(i_{c p}\right)$ and the stability of this state $\left(i_{\min . p}\right)$ are observed, is coincident with the depth, to which the boride precipitates-rich layer was observed in the structure (Figs. 1 and 2). For deeper regions of the borided layer (diffusion zone - Fig. 2), the only differences in the corrosion characteristic are observed above $E=+0.9 \mathrm{~V}$ (Fig. 4b). With the increase in the analyzed depth of the diffusion layer, the material showed an increased tendency to secondary passivation.

In Fig. 5b additionally, dependences of $\Delta E$ vs. $\Delta I$ in the vicinity of $E_{\text {cor }}$ are presented. The slope of $\Delta E / \Delta I$ straight lines represents polarization resistance $\left(R_{p}\right)$ and allows to evaluate corrosion currents for different depths of boronized layer [21]. Assuming that the Tafel slopes are analogous as for iron in sulphate solutions (i.e. $b_{a}=0.04$ and $b_{c}=0.12 \mathrm{~V}$ ) [22] one can find that $i_{\text {cor }}=0.013 R_{p}^{-1}$ where $i_{\text {cor }}$ expressed in $\mathrm{A} \mathrm{cm}^{-2}$ and $R_{p}$ in $\left.\Omega \mathrm{cm}^{2}\right)$.

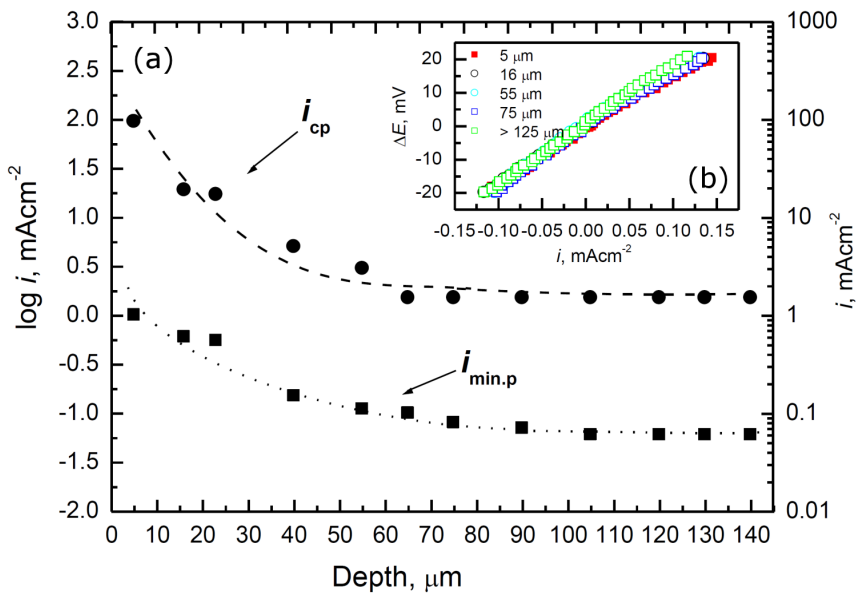

Fig. 5. Depth profiles of the critical passivation current $\left(i_{c p}\right)$ and the minimum current within the passive range $\left(i_{\min . p}\right)(\mathrm{a})$ and the dependences of external currents on the applied potentials in the range of $E_{\text {cor }} \pm 20 \mathrm{mV}$ (b) as a function of grinding depth. 
Calculations have shown that the values of $i_{c o r}$ for all analyzed depths of the surface layer formed as a result of boriding remain practically at a constant level in the range $0.07 \div 0.08 \mathrm{~mA} \mathrm{~cm}^{-2}$.

\section{Conclusion}

The boronizing of AISI 321 steel results in a substantial improvement in the hardness of the surface layer of the material treated. The increase in microhardness is due to the precipitation of boride phases formed in top layers reaching a depth of $70 \mu \mathrm{m}$ into the material.

The corrosion resistance of borided steel AISI 321 is closely related to its composition and phase structure. Enriching the surface of stainless steel with boron impairs its corrosion resistance in acid media, which is the most prominent in the outermost regions of the boron-treated layer. The characteristics of the passive and transpassive states are particularly impaired: boriding causes an increase in the values of the critical passivation current and the minimum current in the passive range, and reduces the tendency to secondary passivation.

\section{References}

[1] Stainless Steels. ASTM Specialty Handbook, ASTM International, Materials Park (OH) 1994.

[2] W.F. Smith, Structure and Properties of Engineering Alloys, McGraw-Hill, New York 1993.

[3] G. Song, Corros. Sci. 47, 1953 (2005).

[4] N.E. Hakiki, S. Boudin, B. Rondot, M. Da Cunha Belo, Corros. Sci. 37, 1809 (1995).

[5] U.I. Thomann, P.J. Uggowitzer, Wear 239, 48 (2000).

[6] I. Ciancaglioni, R. Donnini, S. Kaciulis, A. Mezzi, R. Montanari, N. Ucciardelloa, G. Verona-Rinati, Surf. Interface Anal. 44, 1001 (2012).
[7] Y. Kayali, A. Büyüksagis, Y. Yalçin, Met. Mater. Int. 19, 1053 (2013).

[8] A. Calik, O. Sahin, N. Ucar, Acta Phys. Pol. A 115 694 (2009).

[9] A. Günen, B. Kurt, I. Somunkıran, E. Kanca, N. Orhan, Phys. Met. Metallogr. 116, 896 (2015).

[10] J.H. Yoon, Y.K. Jee, S.Y. Lee, Surf. Coat. Technol. 112, 71 (1999).

[11] Y. Kayali, A. Büyüksagis, I. Günes, Y. Yalçin, Prot. Met. Phys. Chem. Surf. 49, 348 (2013).

[12] I. Mejía-Caballero, M. Palomar-Parvade, J. MartínezTrinidad, M. Romero-Romo, R. Pérez Pasten-Borja, L. Lartundo-Rojas, C. López-Garcia, I. CamposSilva, Surf. Coat. Technol. 280, 384 (2015).

[13] K. Jagielska-Wiaderek, Arch. Metall. Mater. 57, 645 (2012).

[14] K. Jagielska-Wiaderek, H. Bala, T. Wierzchon, Cent. Eur. J. Chem. 11, 2005 (2013).

[15] K. Jagielska-Wiaderek, Int. J. Surf. Sci. Eng. 10, 503 (2016).

[16] K. Przybyłowicz, Theory and Practice of Steel Boriding, Wydawnictwo Politechniki Świętokrzyskiej, Kielce 2001 (in Polish).

[17] Z. Nait Abdellah, M. Keddam, A. Elias, Acta Phys. Pol. A 122, 588 (2012).

[18] M. Keddam, R. Chegroune, M. Kulka, N. Makuch, D. Panfil, P. Siwak, S. Taktak, Trans. Indian Inst. Met. 71, 79 (2018).

[19] Z.N. Abdellah, S. Ulker, S. Taktak, I. Gunes, Mater. Technol. 50, 263 (2016).

[20] S. Taktak, Mater. Des. 28, 1836 (2007).

[21] M. Stern, A.L. Geary, J. Electrochem. Soc. 104, 56 (1957).

[22] H. Bala, Electrochim. Acta 29, 119 (1984). 